\title{
Seismic Strengthening of Weak Bolted end Plate Connections
}

\author{
Hamid Saberi* and Vahid Saberi \\ Department of Civil Engineering, University of Eyvanekey, Iran
}

Submission: July 22, 2017; Published: September 21, 2017

*Corresponding author: Hamid Saberi, Department of Civil Engineering, University of Eyvanekey, Semnan, Iran, Tel: 9-89125E-11,

Email: saberi.hamid@gmail.com

\begin{abstract}
Bolted steel connections have been frequently used after Northridge earthquake. Strengthening of these connections without the need for changing or replacing their components is a problem that has been recently considered by engineers. This study develops and experimentally validates an innovative technique for enhancing the seismic performance of steel beam to column moment connections. The use of haunches or post-tensioned tendons as a way to rehabilitate end plate bolted connections with weak end plate is studied constructing 4 experimental specimens of corner connections under SAC cyclic loading protocol. The results of the study show that this strengthening method improves the cyclic behavior of the weak connections. Besides, it provides specimens with better performance than that of the reference connection designed according to AISC.
\end{abstract}

Keywords: Rehabilitation; Cyclic behavior; Bolted connections; Welded haunch; Post tensioned tendons; End plate

\section{Introduction}

Steel connections are critical structural elements that transfer the floor load to beams and columns. This is due to the important role they in maintaining the overall stability of steel structures. Among the concerns regarding the poor performance of weak connections is the ability to effectively and economically rehabilitate steel moment connections in existing buildings. In the followings, some investigations about the connections and strengthening ways are reviewed. Asada et al. [1] proposed a method to improve plastic deformation capacity of the welded wide flange beam-to-column connections in existing steel buildings by using supplemental $\mathrm{H}$-section haunches jointed by high-strength bolts and welding which expected to secure construction quality. Saberi et al. [2-4] have explored comparison of bolted end plate and T-stub connection sensitivity to component thickness and bolt diameter on cyclic behavior. Behavior of post-tensioned connections with stiffened angles under cyclic loading is studied by Shiravand et al. [5].

\section{Test Specimens}

In this paper, four end-plate bolted beam-to-column connections are tested. The beam profile in all specimens is IPB140 with $1.5 \mathrm{~m}$ length and the column profile is IPB200 with length of $2 \mathrm{~m}$. A reference specimen called EP-R (End Plate Reference) is designed based on AISC [6] and constructed. One weak connection specimens is also constructed. This specimen has weak end plate EP-WP. To evaluate the cyclic behavior of the retrofitted connections using the proposed method, this weak specimen is fabricated again and retrofitted by adding post tensioned tendons EP-WP-T0.6" and retrofitted by adding welded haunches EP-WP-H15. Details of the specimens are shown in Figure 1.

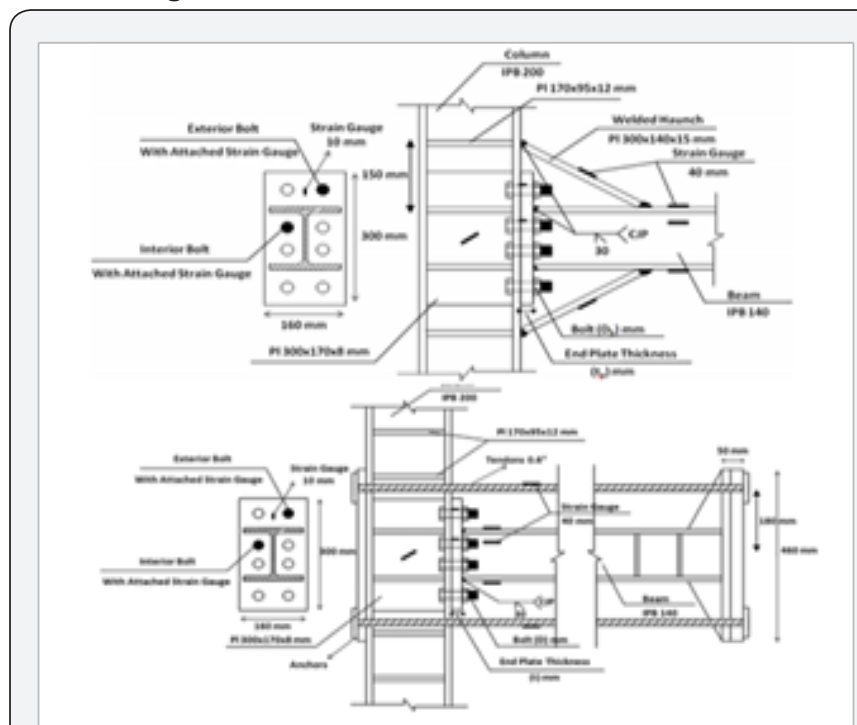

Figure 1: Definition of specimen fabricating parameters and location of strain gauges.

\section{Test Setup}

The total test setup and instrumentation used in the present study are shown in Figure 2. 


\section{Civil Engineering Research Journal}

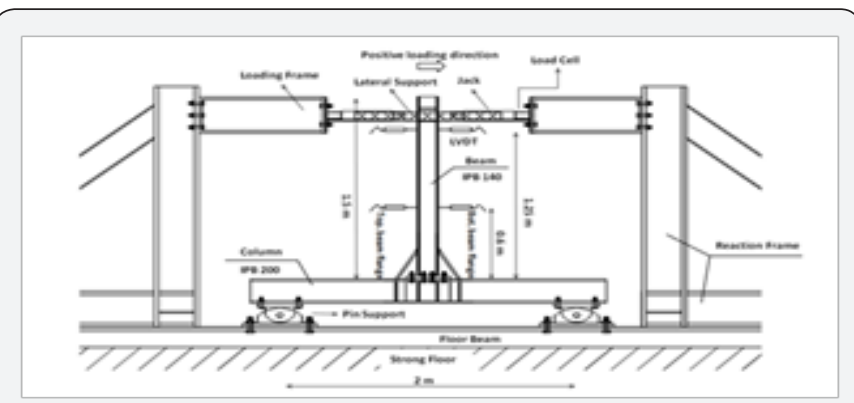

Figure 2: Test setup.

\section{Test Results}

Comparison of the reference specimen EP-R with weak specimen EP-WP shows that the weak end plate results in changing the failure mode from plastic hinge formation in beam to yielding and failure of end plate. Naturally, when the beam remains elastic and its capacities are not used, 64\% reduction in flexural capacity and energy absorption was occurred. By retrofitting this connection in specimen EP-WP-T0.6" with post tensioned tendons; the failure mode is modified to plastic hinge formation in beam. Consequently, yielding occurs in beam and the flexural capacity is increased by 2.9 times and the initial rotational stiffness is increased by $19 \%$.

Comparison of the reference specimen End Plate-Ref with weak specimen EP-WP shows that the weak end plate results in changing the failure mode from plastic hinge formation in beam to yielding and failure of end plate. Naturally, when the beam remains elastic and its capacities are not used, 64\% reduction in flexural capacity and energy absorption was occurred. By retrofitting this connection in specimen EP-WP-H15 using haunch, the failure mode is modified to plastic hinge formation in beam after the haunch that leads to increase of flexural capacity and initial stiffness of the retrofitted connection by 3.7 and 2.3 times respectively (Figure 3).

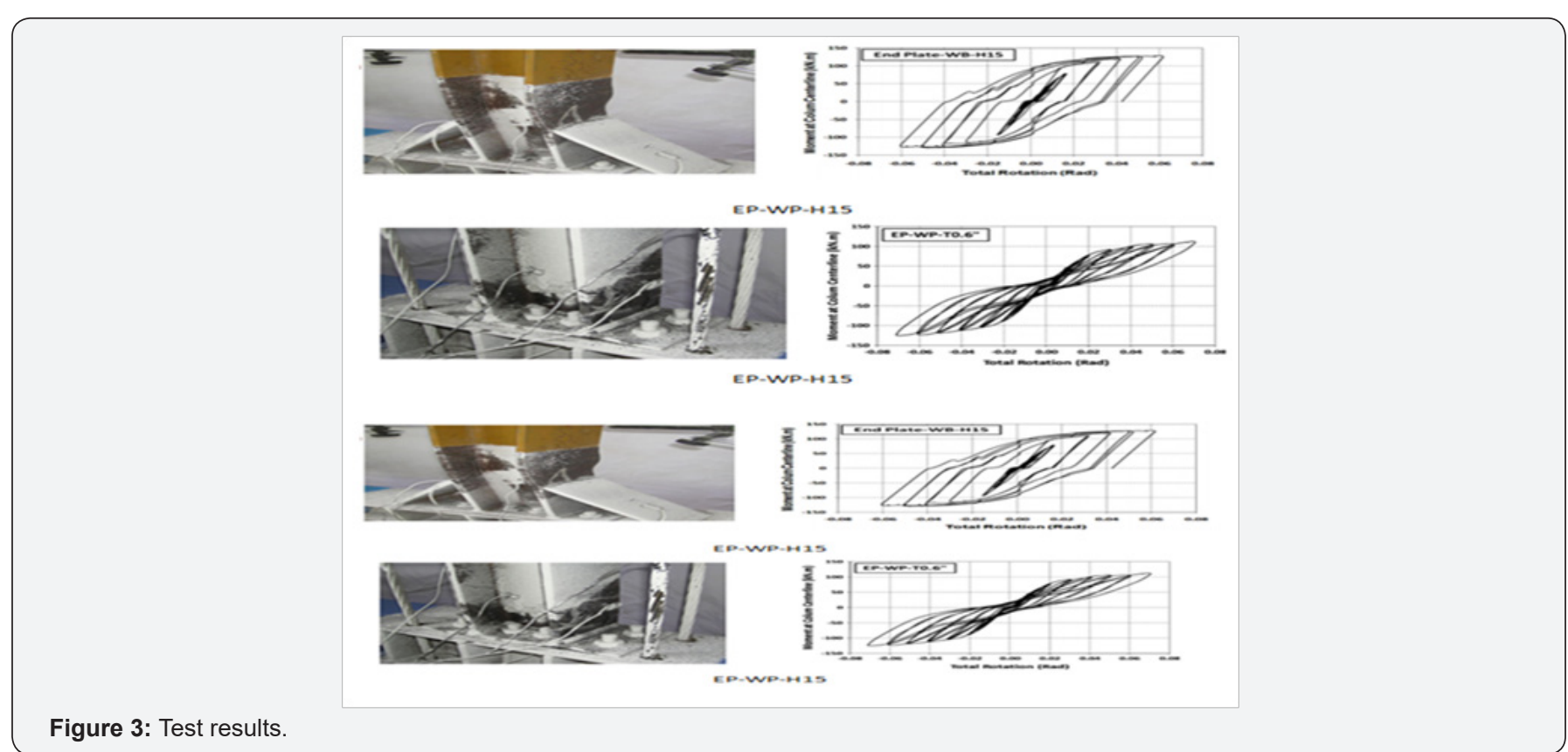

\section{References}

1. Asada H, Tanaka T, Yamada S, Matoba H (2014) Proposal for seismic retrofit of beam-to-column connection by the addition of $\mathrm{H}$-section haunches to beams using bolt connection. International Journal of Steel Structures 14(4): 865-871.

2. Saberi H, Kheyroddin A, Gerami M (2014) Comparison of bolted end plate and T-stub connections sensitivity to bolt diameter on cyclic behavior. International Journal of Steel Structures 14(3): 633-647.

3. Saberi H, Kheyroddin A, Gerami M (2017) Seismic Strengthening of Weak Bolted End Plate Connections Using Welded Haunches. International Journal of Steel Structures 17(2): 743-755.

4. Saberi V, Gerami M, Kheyroddin A (2014) Comparison of bolted end plate and T-stub connection sensitivity to component thickness. Journal of Constructional Steel Research 98: 134-145.

5. Shiravand MR, Mahboub S (2016) Behavior of post-tensioned connections with stiffened angles under cyclic loading. Journal of Constructional Steel Research 116: 183-192.

6. AISC (1980) manual of steel construction ( $8^{\text {th }}$ edn), American Institute of Steel Construction, Chicago, Illinois. 
(C) This work is licensed under Creative Commons Attribution 4.0 License DOI: 10.19080/CERJ.2017.02.555584
Your next submission with Juniper Publishers will reach you the below assets

- Quality Editorial service

- Swift Peer Review

- Reprints availability

- E-prints Service

- Manuscript Podcast for convenient understanding

- Global attainment for your research

- Manuscript accessibility in different formats

( Pdf, E-pub, Full Text, Audio)

- Unceasing customer service

Track the below URL for one-step submission https://juniperpublishers.com/online-submission.php 